\title{
EFEKTIVITAS PENGENALAN AKAN KRISTUS DALAM PEMURIDAN SPK DI GEREJA MAHANAIM COMMUNITY CHURCH SEMARANG
}

\author{
Chandra Kirana Luhur \\ (Dosen Tetap STT Kristus Alfa Omega: davidchandrakirana@gmail.com)
}

\begin{abstract}
Many churches began to outreach through communal facilities in Semarang. This can be seen from the activity of the church in making discipleship for the members.

From these circumstances, researchers feel interested to examine how effective the strategy of cell group leader in reaching new souls based on Act 2-4. To find out the effectiveness strategy of cell group leader to implementation in the outreach of the soul based on Act 2-4 in

the Cell Groups? To know the most dominant dimension in the implementation of the effectiveness of the cell group leader in conducting the outreach by Act 2-4. To know the most influential background on the implementation of the effectiveness of the cell groupleader in conducting the outreach by Act 2-4.
\end{abstract}

Kata kunci: Efektivitas, pengenalan akan Kristus, pemuridan, SPK.

\section{A. PENDAHULUAN}

Saya Pengikut Kristus (SPK) merupakan salah satu alat pemuridan bagi jemaat dan para petobat baru di samping masih begitu banyak lagi cara lainnya yang bisa dipakai oleh pemimpin gereja sebagai alat yang efektif untuk memuridkan jemaat dan para petobat baru dan anggota gereja yang bergabung di gerejanya. SPK adalah pembinaan rohani dasar untuk jemaat aktif dan petobat baru dengan tujuan untuk menjangkau orang-orang yang sudah percaya atau baru percaya agar mengalami Kristus dan memperoleh keselamatan, pemulihan, kuasa dan perubahan hidup, sehingga dapat melayani Tuhan dengan menjadi pembina bagi orang percaya baru lainnya.

SPK cukup efektif dipakai untuk memuridkan petobat baru dan jemaat aktif karena SPK adalah merupakan tempat untuk pemulihan orang-orang yang terluka secara batin dan yang undur dari Tuhan karena kecewa, dengan tujuan agar dapat dibina dan dikembangkan menurut prinsip-prinsip Alkitab guna mengalami pertumbuhan rohani, dengan tujuan akhir adalah seluruh peserta dapat membantu pemimpin gereja dalam menjalankan misi Kristus yaitu menjangkau jiwa dan memuridkan. SPK terdiri dari 3 modul pemuridan yaitu: 1) SPK Pemenang, 2) SPK Pengabdi dan 3) SPK Pemimpin. Dalam penelitian ini yang diambil adalah modul SPK Pemenang. SPK Pemenang adalah sebuah program atau langkah yang terencana untuk mencapai serangkaian tujuan yang telah ditentukan terutama dalam hal pemulihan dan pemuridan jemaat serta penjangkauan jiwa. Pemuridan melalui SPK adalah 
untuk memuridkan para petobat baru dan jemaat agar mereka dapat menyadari akan keselamatan yang telah mereka terima melalui pengorbanan Yesus Kristus di atas kayu salib. Perlunya ada penyelamatan oleh Yesus Kristus adalah karena semua manusia berdosa dan hilang keselamatannya dan segala usaha manusia adalah sia-sia karena keselamatan hanya bisa didapatkan melalui Yesus Kristus. Dilakukan juga pelepasan dari segala ikatan kuasa dosa yang mengikat orang percaya sehingga bisa lepas dan bebas di dalam memuji dan menyembah Tuhan. Proses pemulihan dan pelepasan ini membutuhkan kerjasama antara jemaat, penyelenggara dan Roh Kudus.

Yesus secara khusus membimbing 12 orang murid-Nya karena Dia tahu bahwa suatu saat nanti Dia harus kembali ke Sorga, sehingga dengan membimbing para murid, Yesus ingin karya-Nya itu dapat dilanjutkan oleh mereka melalui proses pelipatgandaan yang melahirkan generasi berikutnya. Dengan demikian, Injil akan dapat secara cepat bukan saja didengar oleh banyak orang tetapi juga dimengerti dan dilakukan oleh orang-orang yang percaya. Setelah kebangkitan Kristus, para rasul juga melakukan penjangkauan terhadap orang-orang yang belum percaya dengan cara melakukan mukjizat dan penginjilan dari satu desa ke desa lainnya. Hasil penjangkauannya tersebut oleh para rasul kemudian diberikan pengajaran Firman dengan tujuan agar nantinya orang baru tersebut juga akan dapat melakukan penjangkauan dan pemuridan yang menghasilkan generasi berikutnya. Pertumbuhan rohani setiap orang dan juga jumlah orang yang menjadi percaya, jelas merupakan kehendak Allah atas gereja-Nya. Demikian juga tujuan pemimpin gereja bukan hanya sekedar meningkatkan jumlah jemaat di gereja, melainkan yang terutama adalah membawa mereka untuk meningkatkan iman percaya mereka kepada Yesus Kristus dan melakukan Amanat Agung Yesus Kristus untuk menjangkau mereka yang belum percaya kepada Yesus Kristus.

Mahanaim Community Church Semarang menyadari betapa pentingnya memuridkan jemaat dan mengajarkan mereka untuk melakukan penjangkauan jiwa, karena itu di Mahanaim mulai dilakukan program pemulihan dan pemuridan untuk penjangkauan jiwa yang dikenal dengan nama Saya Pengikut Kristus (SPK). Tanpa adanya usaha untuk melakukan pemuridan dan penjangkauan jiwa maka gereja akan mengalami stagnasi dalam pertumbuhan jemaat baik dalam hal rohani maupun dalam jumlah kehadiran jemaat. Gereja akan menjadi eksklusif dan akan sulit untuk menerima petobat baru dengan latar belakang yang berbeda dan dengan corak gereja yang sudah ada. 
Gereja yang eksklusif akan kurang mengalami tantangan di dalam memikirkan pertumbuhan jemaat dan lebih menitik beratkan kepada kenyamanan kelompok masingmasing sehingga tidak ada usaha maksimal di dalam memuridkan jemaatnya agar imannya menjadi bertumbuh dan yang bertujuan untuk menjangkau jiwa baru. Program SPK ini sangat dibutuhkan oleh gereja untuk sarana memacu jemaat di dalam pertumbuhan imannya dan mempraktekkan gaya hidup Allah melalui penjangkauan jiwa.

Peneliti melakukan pengamatan mengenai proses pemuridan melalui SPK di Mahanaim Community Church yang sampai saat ini sudah dilaksanakan sebanyak 15 kali dan peneliti melihat begitu banyak peserta yang mengalami pemulihan dari cara hidupnya yang lama dan berubah menjadi pribadi yang baru. Banyak kendala yang dihadapi pengurus dalam mengembangkan komunitas yang ada, terutama dalam hal memuridkan ini karena membutuhkan waktu yang cukup panjang. Latar belakang yang paling mempengaruhi implementasi pemuridan jemaat melalui SPK di Mahanaim Community Church Semarang adalah pengajarannya yang sederhana, sehingga jemaat yang baru dan memiliki iman yang dewasa menjadi tertarik untuk mengikuti program ini.

\section{B. METODOLOGI}

Mahanaim Community Church adalah sebuah gereja yang berlokasi di tengah perumahan yang padat di Kota Semarang, yang terletak di Kawasan Perumahan Puri Anjasmoro Blok. K.6/ 9-12 Semarang. Mahanaim Community Church adalah gereja Pentakosta Kharismatik yang berdiri tahun 1993, yang dahulunya dikenal dengan nama GPdI Mahanaim. Saat ini Mahanaim Community Church Semarang digembalakan oleh Pdt. Agus Setyanto Sarono, M.Th. Jemaat yang tergabung di gereja ini ada sekitar 220 orang, tidak termasuk anak sekolah minggu. Jemaat Mahanaim terdiri dari berbagai suku dan tingkatan ekonomi.

Mahanaim Community Church Semarang adalah salah satu dari sepuluh gereja yang berlindung dalam denominasi Immanuel Community Semarang namun bersifat otonom karena menggunakan sistem kemajelisan yang berhak mengatur internal gereja masingmasing. Salah satu pilar gereja ini adalah SPK dan SPK adalah merupakan alat untuk memuridkan jemaat dan untuk menjangkau jiwa. Hubungan antar jemaat sangat baik sehingga banyak kegiatan di luar kegiatan gereja yang dilakukan secara bersama. Sikap saling menolongpun tampak sangat baik. Pada waktu ada anggota jemaat yang sakit ataupun mengalami musibah maka jemaat yang lainnya segera memberikan dukungan. Rasa 
persaudaraan yang dalam sangat menunjang sehingga ada jiwa baru yang datang untuk bergabung menjadi jemaat.

Gembala setempat juga selalu mendorong para jemaat agar semuanya tergabung di dalam kelompok sel dan juga mengikuti acara-acara kerohanian lainnya yang diadakan di luar gereja lokal. Tujuannya adalah agar para jemaat mengalami pertumbuhan rohani yang baik. Ketika kerohanian jemaat bertumbuh baik maka mereka akan memuridkan orang lain dan melakukan penjangkauan jiwa dengan kerelaan sendiri. Jemaat yang pernah mempunyai pengalaman pribadi dengan Tuhan melalui jamahan dan pertolongan Tuhan yang secara langsung merupakan jemaat yang radikal di dalam Kristus. Mereka akan membagikan pengalaman pribadi mereka kepada orang-orang yang ada di sekitar mereka.

Mahanaim Community Church Semarang menyadari betapa pentingnya melakukan proses pemuridan dan penjangkauan jiwa terhadap pertumbuhan gereja dan jemaat, oleh karena itu Mahanaim Community Church Semarang mulai melakukan pelatihan pemuridan SPK sejak tahun 2003. Perkembangan SPK selama enam belas tahun mengalami pasang surut terutama di dalam proses pemuridan untuk penjangkauan jiwa karena kurangnya kesadaran jemaat akan pentingnya mengabarkan Injil. Pengetahuan pemimpin dalam mengembangkan SPK inipun kurang karena tidak adanya variasi pengembangan metode yang dipakai. Kunci pembinaan rohani yang efektif: 1) Mengalami Kristus, setiap peserta mengalami perjumpaan Ilahi dengan Tuhan lewat firman Tuhan dan pelayanan pribadi. Firman Tuhan disampaikan dengan sederhana disertai kesaksian; 2) Membangun hubungan, setiap peserta berada dalam kelompok dengan komposisi 1 pembina dan 2 peserta sehingga bisa dilayani dengan efektif. Pembina dan peserta membangun hubungan dengan keterbukaan. Keterbukaan adalah awal dari pemulihan. Pembina harus berorientasi kepada jiwa dan bukan program. Pembina melakukan tindak lanjut di luar kelas pemuridan melalui telpon dan kunjungan secara rutin.

Ada indikasi bahwa latar belakang yang paling mempengaruhi implementasi para peserta SPK dalam mengikuti program ini adalah karena tertarik untuk dapat melakukan penjangkauan jiwa melalui proses pemuridan yang dilakukan di dalam program SPK. Proses pemuridan dilakukan setiap minggu selama 3 bulan dan ini membuat para peserta terikat untuk terus mengikutinya. SPK berkembang akan menghasilkan murid Kristus yang siap untuk menjangkau orang lain yang belum percaya. Prinsip berbuah dan berlipat ganda adalah merupakan pola yang Tuhan inginkan bagi jemaatnya. Peneliti melakukan pengamatan terhadap efektivitas pemuridan melalui SPK terhadap petobat baru dan jemaat di Mahanaim Community Church Semarang yang saat ini sudah melaksanakan total 15 kali program SPK . 
Banyak kendala yang dihadapi pengurus di Mahanaim Community Church Semarang dalam usaha untuk mengembangkan komunitas yang ada, terutama dalam hal pemuridan jemaat yang berkesinambungan.

Berdasarkan pengamatan peneliti ada indikasi para peserta SPK pada umumnya belum memiliki wawasan yang cukup akan firman Tuhan dan kurang memiliki kemampuan untuk menjangkau jiwa dengan baik. Peserta dipilih berdasarkan keinginan mereka untuk bergabung di SPK tanpa memperhatikan tingkat pemahaman mereka akan firman Tuhan. Peneliti merasa perlunya ditingkatkan kesadaran peserta SPK akan salah satu tujuan utama SPK adalah memuridkan dengan tujuan untuk melakukan penjangkauan jiwa.

Penyelenggaraan SPK di Mahanaim dilakukan hampir setahun sekali dan ini menarik minat peneliti untuk meneliti strategi yang dipakai para pemimpin gereja memuridkan petobat baru dan jemaat dan melatih mereka di dalam penjangkauan jiwa yang sudah diterapkan, sehingga bisa dilihat sejauhmana efektivitas dan implementasi penyelenggaraan program SPK ini dalam pemuridan bagi peserta.

Metode penelitian: penelitian ini lebih merupakan proses penemuan dari pada uji hipotesis, menekankan perhatian pada fungsi dari pada mekanisme, lebih menekankan hasil dan kesimpulan secara kuantitatif. ${ }^{1}$ Populasi dan sampel: populasi dalam penelitian ini diambil dari peserta SPK yang setiap angkatannya adalah minimal 20 orang. Tehnik pengumpulan data : Penelitian ini juga menggunakan teknik pengumpulan data melalui angket atau kuesioner "Questinnaires are form used in a survey design that participation in a study complete and return to the researcher" ${ }^{2}$ Kuesioner atau angket ini dibagikan kepada 20 responden dan peneliti menggunakan enumerator-enumerator guna membantu pengumpulan data. Tehnik pengumpulan data dalam penelitian ini adalah pengumpulan data secara langsung oleh peneliti, setelah responden mengisi angket yang telah dibagikan.

"Pengumpulan data merupakan langkah yang amat penting, karena data yang akan dikumpulkan akan digunakan untuk pemecahan masalah yang sedang diteliti atau untuk menguji hipotesis yang telah dirumuskan". ${ }^{3}$ Tehnik analisa dalam penelitian ini dengan menggunakan: penyajian data dalam bentuk tabel, bentuk grafik dan diagram serta deskripsi

${ }^{1}$ Gidion, "Efektifitas Kepemimpinan Yang Memberdayakan Dalam Meningkatkan Pertumbuhan Gereja Di Gereja Jemaat Kristen Indonesia Maranatha Ungaran," Shift Key 8, no. 1 (2018): 16-33, http://jurnal.sttkao.ac.id/index.php/shiftkey/article/view/14.

${ }^{2}$ Sugiyono, "Metode Penelitian Kombinasi (Mixed Methods)," Bandung: Alfabeta (2010): 230.

${ }^{3}$ Syofian Siregar, Statistik Parametrik Untuk Penelitian Kuantitatif (Jakarta: Bumi Aksara, 2014), 39. 
data yang menggambarkan karakteristik atau sekelompok data yang dianalisis menggunakan statistik deskriptif (ukuran pemusatan data yaitu mean, median dan modus) dan ukuran penyebaran data (rentang, simpangan baku dan varian). Variabel dalam penelitian ini yaitu efektivitas pengenalan akan Kristus dalam pemuridan SPK di Mahanaim Community Church.

\section{PEMBAHASAN}

Proses pemuridan merupakan salah satu cara dari gereja lokal untuk mendidik jemaatnya untuk menjadi semakin dewasa dalam Tuhan. Proses pemuridan pada umumnya memerlukan cukup banyak waktu karena di dalam pemuridan itu dilakukan sebuah proses perubahan katakter manusia lama menjadi karakter yang baru yaitu karakter yang serupa dengan Kristus. Kata murid dan pemuridan sering dipergunakan sehingga maknanya tidak jelas atau lemah. Kata-kata tersebut juga sering diartikan dengan sesuka hati oleh para penggunanya. Jika kita ingin memahami pengajaran Tuhan Yesus mengenai pemuridan, kita harus memahami atau mengerti apa yang Ia maksudkan dengan istilah tersebut, bukan apa yang kita maksudkan. Kita harus menguji penjelasan-penjelasan tentang pemuridan dalam pengajaran Yesus dan murid-murid-Nya supaya kita bisa belajar mengenai konsep pemuridan yang sejati. ${ }^{4}$

Seorang murid adalah seorang siswa, seorang pelajar. Pemuridan adalah suatu proses ketika seorang mentor melatih dan membantu seseorang belajar tentang sesuatu dan melakukan sesuatu secara praktis. Waktu Tuhan Yesus memilih murid-murid, "Ia menetapkan dua belas orang supaya mereka berada bersama Dia dan supaya Dia mengutus mereka untuk berkhotbah." (Mrk. 3:14). Para murid itu hidup bersama Juruselamat, mendengarkan pengajaran-Nya, mengamati gaya hidup-Nya, dan kemudian bergerak keluar untuk menyebarkan dan memberitakan pesan-pesan-Nya. Inilah suatu bentuk pelatihan secara praktis di lapangan. Pemuridan juga dapat dilihat dalam surat Paulus kepada Timotius, "Halhal yang telah engkau dengarkan dari padaku di antara banyak saksi, percayakanlah hal-hal itu kepada orang-orang yang setia, yang juga cakap mengajar orang lain.” (2 Tim. 2:2).

Umat Tuhan dapat belajar bahwa dalam ayat ini ada empat "generasi" orang percaya, yaitu Paulus, Timotius, orang-orang yang dapat dipercaya, dan orang-orang lain. Penyebaran

${ }^{4}$ Gidion, "Efektifitas Kepemimpinan Yang Memberdayakan Dalam Meningkatkan Pertumbuhan Gereja Di Gereja Jemaat Kristen Indonesia Maranatha Ungaran," Shift Key 8, no. 1 (2018): 16-33. 
iman Kristen bergantung pada keterlibatan setiap orang percaya di dalam proses perlipatgandaan ini. Pelatihan ini pasti merupakan cara yang paling baik. Jika ada cara yang lebih baik, Tuhan Yesus pasti telah menggunakannya. Amanat Agung itu sangat penting, bukan saja karena merupakan misi utama semua gereja, tetapi juga karena gereja-gereja lokal akan terbentuk apabila ada orang-orang yang taat melaksanakan Amanat Agung tersebut. “(28:18) Yesus mendekati mereka dan berkata: 'Kepada-Ku telah diberikan segala kuasa di sorga dan di bumi. (28:19) Karena itu pergilah, jadikanlah semua bangsa murid-Ku dan baptislah mereka dalam nama Bapa dan Anak dan Roh Kudus, (28:20) dan ajarlah mereka melakukan segala sesuatu yang telah Kuperintahkan kepadamu. Dan ketahuilah, Aku menyertai kamu senantiasa sampai kepada akhir zaman" (Mat 28:18-20; Mrk 16:15-20; Luk 24:47-51; Yoh 20:21-22; Kis 1:4-9).

Tanpa Amanat Agung tidak akan ada gereja-gereja lokal. Pelaksanaan Amanat Agung menghasilkan gereja-gereja lokal. Gereja ada karena Amanat Agung dan untuk Amanat Agung. Dengan demikian Amanat Agung merupakan perintah bukan pilihan dan keharusan bukan sekedar progam. Melaksanakan Amanat Agung adalah tujuan gereja karena Amanat Agung merupakan esensi gereja. Amanat Agung adalah perintah yang berlaku terus

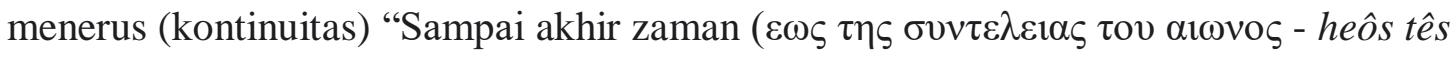
sunteleias tou aiônos)". Frase Yunani "sunteleias tou aiônos" berarti "mengakhiri, menyudahi, dan menyelesaikan". Kata ini digunakan khusus untuk menyatakan akhir zaman.

Beberapa orang memahami bahwa inti Amanat Agung terletak hanya pada penginjilan (Mat 28:19-20). Pemahaman tersebut didasarkan pada penekanan kata "pergilah" yang diletakkan di awal kalimat yang diikuti langkah selanjutnya yaitu menjadikan murid, membaptis dan mengajar. Tetapi jika diperhatikan menurut struktur tata bahasa Yunani ayat 19-20 dari Matius 28 tersebut, maka inti Amanat Agung justru terletak pada pemuridan. Perhatikanlah empat kata kerja pergilah ( $\pi \circ \rho \varepsilon v \theta \varepsilon v \tau \varepsilon \varsigma$ poreuthentes), jadikanlah murid

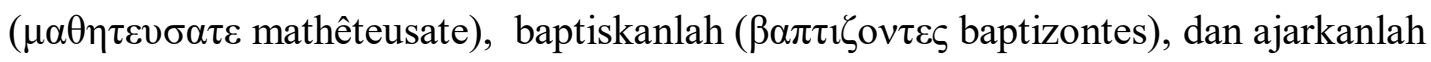
( $\delta 1 \delta \alpha \sigma \kappa o v \tau \varepsilon \varsigma$ didaskontes)". Kata “pergilah, baptiskanlah, ajarkanlah" adalah kata kerja partisip atau bentuk kata kerja bantu. Kata "jadikanlah semua bangsa murid-Ku $\{\mu \alpha \theta \eta \tau \varepsilon v \sigma \alpha \tau \varepsilon$ $\pi \alpha v \tau \alpha \tau \alpha \varepsilon \theta v \eta$; mathêteusate panta ta ethnê; jadikanlah murid(-Ku) semua bangsa-bangsa\}" adalah kata kerja imperatif atau kata kerja bentuk perintah. Imperatif artinya suatu panggilan yang berbentuk perintah mutlak dan tidak bisa ditawar-tawar.

Proses pelaksanaan Amanat Agung yang di dalamnya terdapat siklus empat langkah untuk menjangkau dunia bagi Kristus adalah sebagai berikut : (1) Dunia hanya dapat 
dijangkau jika murid-murid Kristus pergi memberitakan Injil dan bersaksi; (2) Sementara itu, orang-orang yang telah mendengarkan Injil dan percaya serta mengambil keputusan untuk mengikut Kristus harus menyatakan pengakuan imannya di muka umum dan memberi diri untuk dibaptis ke dalam air. Baptisan adalah kesaksian awal yang dapat dilihat dari luar tentang pengalaman seseorang dengan Kristus; (3) Kemudian, orang-orang yang baru menjadi pengikut Kristus itu disebut orang percaya dengan status sebagai murid Kristus yang harus diajarkan perintah-perintah (ajaran-ajaran) Tuhan kita dan dibimbing untuk melakukan (praktek) perintah-perintah itu dalam ketaatan, sukacita dan kasih kepada Kristus menuju kedewasaan melalui proses pemuridan di gereja lokal; (4) Orang-orang percaya telah dimuridkan dan dilengkapi itu diutus untuk menjangkau orang-orang yang belum percaya dengan "pergi menjadikan semua bangsa murid Kristus". Siklus multiplikasi ini kembali ke titik awal dan jika dilaksanakan akan menghasilkan lingkaran kesaksian yang terus menerus semakin besar "sampai akhir zaman". Jadi pemuridan nampaknya merupakan metode yang ditetapkan Allah dalam perintah Amanat Agung tersebut untuk mengijili dan menjangkau dunia bagi Kristus. Dengan demikian, jelaslah bahwa penekanan utama atau sasaran Amanat Agung adalah "menjadikan semua bangsa murid Kristus. ${ }^{5}$ Tugas para murid Kristus itu adalah menjadikan segala bangsa murid Kristus, bukan hanya sekedar menghasilkan orang yang mengaku percaya kepada Kristus. Artinya, murid sejati dari Kristus, yang telah belajar dan bertumbuh menjadi dewasa itu, juga dipanggil untuk menghasilkan murid Kristus yang baru.

Demikianlah seterusnya secara berkelanjutan proses pemuridan itu harus berlangsung, murid menghasilkan murid. Salah satu tanda murid Kristus yang sejati adalah menghasilkan murid Kristus yang lainnya. Itulah juga yang dipesankan rasul Paulus kepada muridnya, Timotius, “Apa yang telah engkau dengar dari padaku di depan banyak saksi, percayakanlah itu kepada orang-orang yang dapat dipercayai, yang juga cakap mengajar orang lain" (2 Tim 2:2). Rasul Paulus berhasil memuridkan Timotius, dan Timotius diperintahkan untuk menghasilkan murid Kristus lainnya, yang juga cakap mengajar orang lain hingga bisa menghasilkan lagi murid Kristus yang lainnya. Inilah yang disebut dengan multiplikasi murid Kristus dalam proses pemuridan. Dengan melaksanakan hal ini, sesungguhnya kita sudah melakukan kehendak Allah.

${ }^{5}$ Gidion, "Profesionalitas Layanan Gereja," Shift Key 7, no. 2 (2017): 89-104. 


\section{Pengertian Murid dan Pemuridan}

Kata Yunani untuk "murid" adalah "mathetes" yang menunjuk kepada para pengikut Yesus. Penggunaan paling umum kata "mathetes" adalah untuk menunjuk kepada para pengikut Kristus. Jadi kata "mathetes” menunjuk kepada para pengikut Yesus atau orangorang yang mengaku Yesus adalah Kristus dan Tuhan, mengikuti teladan dan ajaran-Nya, serta melaksanakan perintah-perintah-Nya. Kata "mathetes" yang diterjemahkan "murid" ini tercatat dalam Perjanjian Baru sebanyak 269 kali, sedangkan kata "Kristen" dicatat hanya 3 kali, dan kata "orang percaya" hanya 2 kali. Fakta ini memberitahukan kita bahwa betapa pentingnya panggilan Tuhan Yesus bagi kita supaya menjadi murid-Nya yang sejati. Dengan demikian program-program dan kegiatan-kegiatan gereja lokal tidak boleh lepas dari tugas pemuridan.

Seorang murid Kristus yang sejati adalah seorang yang telah diselamatkan. Seorang murid adalah seorang yang telah dilahirkan kembali (regenerasi) oleh Roh Kudus. Mereka percaya dalam hatinya dan mengaku dengan mulutnya bahwa Yesus adalah Tuhan (Rom 10:9-10). Dengan demikian, secara teologis seseorang menjadi murid Kristus ketika kuasa Roh Kudus turun atasnya dan menjadikannya suatu ciptaan baru (2 Kor. 5:17). Keselamatan itu semata-mata adalah anugerah Allah, yang artinya, tidak ada sedikitpun melibatkan jasa dan usaha manusia (Ef. 2:8-9).

Saat seseorang mendapatkan anugerah hidup kekal seketika itu juga ia diselamatkan dan menjadi murid Kristus (Yoh. 3:16; 14:6; Kis. 4:10-12). Dengan demikian, konsep "menjadikan murid" dalam perintah Amanat Agung adalah memberitakan Injil kepada orangorang yang tidak percaya, dan kemudian mengajak mereka untuk percaya kepada Kristus dan menyerahkan hidup kepada-Nya. Setelah seseorang percaya kepada Kristus dan diselamatkan, ia tidak secara otomatis menjadi dewasa. Ia harus bertumbuh dalam kasih karunia dan pengenalan akan Tuhan dan Juruselamat-Nya, Yesus Kristus (2 Pet 3:18), hingga imannya semakin teguh, berakar kuat dan berbuah lebat dalam Kristus menuju kedewasaan yang penuh (Kol 2:6-7). Inilah proses pemuridan, yaitu pengudusan menuju kedewasaan. Karena itu seorang murid Kristus harus terus berusaha bekerjasama dengan Roh Kudus untuk bertumbuh dalam kasih karunia menuju kedewasaan (Rom. 5:2; 1 Kor. 15:10; Fil. 2:12; 2 Tim. 2:1; Ibr. $12: 15 ; 13: 9 ; 2$ Pet. $3: 18)$.

Menerima keselamatan dan menjadi murid Kristus itu semata-mata adalah anugerah. Seseorang masuk sorga bukan karena ia mengikuti pemuridan, melainkan karena ia telah menerima anugerah hidup kekal dalam Kristus. Jadi pemuridan bukanlah semacam "passport" 
untuk masuk sorga, melainkan suatu proses pengudusan menuju kedewasaan dan menjadi serupa dengan Kristus (Rom 8:29). Pemuridan merupakan hasil suatu kerjasama seumur hidup orang percaya dengan Roh Kudus yang tinggal di dalamnya. Kedewasaan itu sekalipun terjamin akan terjadi, namun tidak terjadi secara otomatis. Masing-masing orang percaya mempunyai peran dan tanggung jawab di dalamnya melalui pemuridan.

\section{Tujuan Pemuridan: Proses Menuju Kedewasaan}

Ketika seseorang diselamatkan, seketika ia mendapatkan hidup yang baru dan menjadi ciptaan baru dalam Kristus. Alkitab mengatakan, "Jadi siapa yang ada di dalam Kristus, ia adalah ciptaan baru: yang lama sudah berlalu, sesungguhnya yang baru sudah datang" (2 Kor. 5:17). Hidup baru atau ciptaan baru ini disebut dengan istilah "regenerasi”. Regenerasi merupakan perubahan supranatural dan sepenuhnya merupakan tindakan Allah tanpa melibatkan manusia (Yoh. 3:6). Manusia yang telah mati secara rohani tidak mungkin dapat bekerjasama dengan Allah untuk menghidupkan dirinya sendiri, karena itu regenerasi merupakan tindakan Allah dan manusia hanya menerimanya. Regenerasi ini merupakan perubahan yang terjadi secara seketika, bukan suatu proses bertahap.

Paulus mengatakan, "telah menghidupkan kita bersama-sama dengan Kristus, sekalipun kita telah mati oleh kesalahan-kesalahan kita oleh kasih karunia kamu diselamatkan" (Ef. 2:5). Kata kerja yang diterjemahkan "menghidupkan” adalah "synezoopoiesen", memakai bentuk aorist tense yang berarti tindakan yang seketika atau sekejap. Regenerasi yang kita alami merupakan perubahan yang radikal, suatu perubahan pada akar natur kita. Dengan demikian regenerasi berarti penanaman (pemberian) kehidupan rohani yang baru, karena pada dasarnya manusia telah mati secara rohani (Ef. 2:5; Kol. 2:13; Rom. 8:7-8). Bersamaan dengan penanaman kehidupan rohani yang baru tersebut, terjadi perubahan yang total yaitu perubahan yang mempengaruhi seluruh keberadaan kepribadian kita meliputi: pikiran, hati nurani, kehendak, dan emosi. Karena regenerasi merupakan pemberian hidup yang baru, maka artinya regenerasi merupakan awal dari proses pembaharuan hidup rohani. Dengan demikian, orang yang lahir baru telah mengalami langkah pertama dari pembaharuan. Proses hidup yang mengikuti regenerasi itu bersifat progresif dan disebut "pengudusan yang dinamis".

Paulus mengingatkan "..karena kamu telah menanggalkan (apekdysamenoi) manusia lama (palaion anthropos) serta kelakuannya, dan telah mengenakan (endysamneoi) manusia baru (kainon anhtropos) yang terus-menerus diperbaharui untuk memperoleh pengetahuan 
yang benar menurut gambar Khaliknya” (Kol. 3:9-10). Paulus dalam ayat ini bukan bermaksud memberitahukan orang-orang percaya di Kolose bahwa mereka sekarang atau setiap hari harus menanggalkan manusia lama dan mengenakan manusia baru berulang-ulang kali, tetapi Paulus menegaskan bahwa mereka telah mengalaminya pada saat regenerasi dan telah melakukan perubahan ini, hal ini terjadi pada saat konversi, ketika mereka menerima dengan iman akan apa yang telah dikerjakan Kristus bagi mereka.

Kata Yunani menanggalkan (apekdysamenoi) dan mengenakan (endysamneoi) menggunakan bentuk aorist tense yang mendeskripsikan kejadian seketika. Jadi Paulus sedang merujuk kepada apa yang telah dilakukan orang percaya di Kolose ini di masa yang lalu. Lalu apakah yang dimaksud Paulus dengan frase "terus menerus diperbaharui"? Artinya, walaupun orang-orang percaya adalah pribadi-pribadi baru, akan tetapi mereka belumlah mencapai kesempurnaan yang tanpa dosa; mereka masih harus bergumul melawan dosa. Pembaharuan ini terus berlanjut dan merupakan proses seumur hidup. Melalui frase ini rasul Paulus menjelaskan kepada kita bahwa setelah lahir baru kita harus terus menerus mengalami proses pengudusan mencakup pengudusan pikiran, kehendak, emosi, dan hati nurani. Alkitab menyebutnya dengan istilah "pengudusan", yang bersifat dinamis bukan statis, yang progresif bukan seketika; yang memerlukan pembaharuan, pertumbuhan dan transformasi terus menerus (1 Tes 5:23; Ibr10:14; 2 Pet 3:18). Proses pengudusan yang progresif dan dinamis ini disebut juga proses pemuridan.

Paulus dalam Efesus 4:23 mengingatkan orang percaya "supaya kamu dibaharui (ananeousthai) di dalam roh dan pikiranmu". Bentuk infinitif "ananeousthai" yang diterjemahkan dengan "dibaharui" adalah bentuk present tense yang menunjuk kepada suatu proses yang berkelanjutan. Jadi, orang-orang percaya yang telah lahir baru dan menjadi ciptaan baru di dalam Kristus masih diperintahkan untuk mematikan perbuatan-perbuatan daging dan segala sesuatu yang berdosa di dalam diri mereka berupa keinginan-keinginan daging (Rom. 8:13; Kol. 3:5), serta menyucikan diri dari segala sesuatu yang mencemari tubuh dan roh (2 Kor. 7:1). Dengan demikian, pemuridan itu adalah suatu proses pertumbuhan yang membuat seseorang maju secara progresif dalam usaha menjadi serupa dengan Kristus.

Pemuridan merupakan proses yang membawa orang percaya meninggalkan sifat bayi dan kanak-kanak rohani lalu bertumbuh menjadi dewasa rohani (Ef. 4:13-17) dan menjadi serupa dengan Kristus (Rom 8:29; Gal 4:19). Yesus sendiri mengatakan, "Seorang murid tidak lebih dari pada gurunya, atau seorang hamba dari pada tuannya. Cukuplah bagi seorang murid jika ia menjadi sama seperti gurunya dan bagi seorang hamba jika ia menjadi sama 
seperti tuannya" (Mat. 10:24-25b). Jelaslah bahwa pemuridan tidak terjadi secara instan, melainkan proses pembelajaran seumur hidup. Ketika seseorang diselamatan, maka ia telah masuk dalam daftar sebagai murid Kristus untuk mengikuti pemuridan dan diperkenalkan kepada kurikulum-Nya. Ini merupakan proses belajar seumur hidup hingga kita menjadi dewasa rohani.

\section{Menjadi Orang Kristen yuang Bertumbuh}

Tugas seorang murid adalah belajar. Berhenti belajar sama dengan berhenti bertumbuh. Banyak orang yang mengaku sebagai orang Kristen tetapi karakternya tidak berubah. Mengapa? Karena mereka tidak mau belajar dan dimuridkan. Yesaya 1:17 mengatakan, "Berhenti berbuat jahat, belajarlah berbuat baik". Akibat dari dosa maka manusia tidak perlu belajar berbuat jahat, tetapi untuk berbuat baik setiap orang perlu belajar. Menjadi murid memang tidak mudah, harus ada penyangkalan diri, tetapi hasilnya luar biasa yaitu kehidupan Yesus semakin nyata dalam hidup kita. Seorang pelatih olah raga mengatakan bahwa jika seseorang ingin mahir dalam salah satu cabang olahraga, ia harus berlatih selama kurang lebih delapan tahun. Demikian juga dengan Kekristenan. Setelah diselamatkan, setiap orang Kristen wajib menjalani pemuridan menuju kedewasaan rohani. Menjadi dewasa rohani tidak terjadi secara instan, melainkan suatu proses. Karena itu, pemuridan adalah suatu proses pertumbuhan menuju kedewasaan rohani. Tujuan kedewasaan rohani adalah menjadi serupa dengan Kristus dengan cara menjadi pengikut Kristus setiap hari dalam pertumbuhan dan perkembangan yang sehat dan baik (Rom. 8:29; Gal. 4:19; Ef. 4:13-17). Walaupun anugerah keselamatan yang diberikan itu sama, fasilitas yang disediakan dan diberikan Allah untuk bertumbuh juga sama, namun kualitas pertumbuhan rohani setiap orang percaya bisa berbeda satu dengan lainnya. Mengapa? Karena dalam pertumbuhan rohani menuju kedewasaan melibatkan peran dan tanggung jawab setiap individu orang percaya.

Rumus dari pertumbuhan rohani adalah "kecepatan dikalikan waktu sama dengan jarak". Artinya kecepatan seseorang bertumbuh dalam kehidupan rohani dalam sejumlah waktu yang diberikan kepadanya akan menentukan seberapa jauh ia sudah dalam perjalanan menuju kedewasaan. Sebagai contoh, seorang yang baru diselamatkan, menjadi murid Kristus yang berkomitmen, dengan penuh semangat dan gairah, mudah diajar dan mau belajar, tekun belajar firman, berdoa dan beribadah, akan bertumbuh menuju kedewasaan lebih cepat dibandingkan dengan seseorang yang sudah diselamatkan dan menjalani kehidupan Kristen 
selama sepuluh tahun, namun membuang waktu dengan banyak hal yang sia-sia, yang tidak menunjang pertumbuhan rohaninya.

Rasul Paulus menjelaskan rumus pertumbuhan ini kepada jemaat di Korintus ketika ia berkata, "Dan aku, saudara-saudara, pada waktu itu tidak dapat berbicara dengan kamu seperti dengan manusia rohani, tetapi hanya dengan manusia duniawi, yang belum dewasa dalam Kristus. Susulah yang kuberikan kepadamu, bukanlah makanan keras, sebab kamu belum dapat menerimanya. Dan sekarang pun kamu belum dapat menerimanya. Karena kamu masih manusia duniawi. Sebab, jika di antara kamu ada iri hati dan perselisihan bukankah hal itu menunjukkan, bahwa kamu manusia duniawi dan bahwa kamu hidup secara manusiawi?" (1 Kor. 3:1-3). Ayat di atas menjelaskan kepada kita bahwa Rasul Paulus mengharapkan jemaat di Korintus telah menjadi dewasa secara rohani dalam suatu jangka waktu yang telah dilewati, tetapi kenyataannya, mereka masih bertindak seperti bayi dalam kerohanian. Rasul Paulus ke Korintus sekitar tahun 50 M, dan melalui pelayanan penginjilannya ada orangorang dituntun dan percaya kepada Kristus. Kira-kira tahun 55 M, yaitu kira-kira lima atau enam tahun kemudian, Rasul Paulus menulis surat kepada jemaat di Korintus, yaitu surat 1 Korintus.

Dalam surat itu ia menekankan bahwa seharusnya jemaat di Korintus telah menjadi dewasa bila ditinjau dari sudut waktu yang telah dilewati, namun kenyataan mereka masih bayi rohani. Artinya, waktu yang seharusnya cukup untuk proses pertumbuhan rohani tidak dimanfaat dengan sebaik-baiknya untuk bertumbuh. Di dalam 1 Korintus 2:14 - 3:3, Paulus nampaknya memberikan empat golongan manusia yang berhubungan dengan kehidupan rohaninya : (1) Manusia duniawi (1 Kor. 2:14), yaitu orang non Kristen, yang belum lahir baru, dan karena itu tidak dapat memahami hal-hal rohani yang dari Allah; (2) Orang Kristen bayi (1 Kor. 3:1), yaitu orang yang telah dilahirkan baru dalam Kristus dan diselamatkan. Bayi-bayi secara rohani ini akan bertumbuh dan berkembangan menuju kedewasaan apabila mereka mengikuti proses pemuridan yang sehat dan baik; (3) Orang Kristen Dewasa (1 Kor. 2:15-16), yaitu orang Kristen yang memiliki pikiran Kristus, dan memiliki panca indera yang terlatih sehingga dapat mengadakan pilihan berdasarkan pengetahuan tentang Allah (Ibr. 5:14). Mereka adalah murid yang telah bertumbuh dan berkembang dengan sehat dan baik dalam proses pemuridan; dan (4) Orang Kristen Stagnan (1 Kor 3:2-3), yaitu orang Kristen yang tidak bertumbuh atau hanya sedikit bertumbuh.

Orang Kristen stagnan masih tetap bayi dan atau kanak-kanak rohani walaupun telah mendapat waktu dan kesempatan yang cukup untuk menjadi dewasa (Ibr 4:11-13). Mereka 
sudah diselamatkan, namun masih berpola pikir dan bertindak seperti orang duniawi. Mereka menolak panggilan dan tantangan dalam proses pemuridan. Penulis kitab Ibrani menjelaskan demikian, "Tentang hal itu banyak yang harus kami katakan, tetapi yang sukar untuk dijelaskan, karena kamu telah lamban dalam hal mendengarkan. Sebab sekalipun kamu, ditinjau dari sudut waktu, sudah seharusnya menjadi pengajar, kamu masih perlu lagi diajarkan asas-asas pokok dari penyataan Allah, dan kamu masih memerlukan susu, bukan makanan keras. Sebab barangsiapa masih memerlukan susu ia tidak memahami ajaran tentang kebenaran, sebab ia adalah anak kecil. Tetapi makanan keras adalah untuk orang-orang dewasa, yang karena mempunyai pancaindera yang terlatih untuk membedakan yang baik dari pada yang jahat (Ibr. 5:11-14).

Supaya dapat bertumbuh sehat dan baik secara rohani, orang-orang Kristen harus melatih dan mendisplin diri secara rohani dengan melakukan lima hal berikut : 1) Ibadah, yang membawa memiliki hubungan pribadi dengan Allah; 2) Persekutuan, yang membawa mereka dalam hubungan yang penuh kasih dan suasana keakraban dengan sesama orang percaya lainnya; 3) Pengajaran, yang membawa mereka belajar firman sesuai dengan tikatannya dan dilengkapi dalam proses pertumbuhan rohani yang sehat hingga mencapai kedewasaan; 4) Pelayanan, yang membantu mereka untuk menemukan, mengembangkan dan menjalankan berbagai karunia, talenta dan berbagai kemampuan lainnya dalam melayani Kristus dan orang percaya lainnya; dan 5) Penginjilan, yang mebawa mereka untuk bersaksi dan menjangkau orang-orang belum percaya kepada Kristus. Pertumbuhan rohani yang sehat harus memperhatikan kelima faktor tersebut dan tidak boleh mengabaikan satupun diantara kelima hal tersebut.

\section{Harga Sebuah Pemuridan}

Sesungguhnya, karena kematian dan korban Kristus di kayu salib maka jalan untuk selamat itu telah menjadi begitu sederhana, yaitu hanya dengan percaya kepada Yesus Kristus sebagai Tuhan dan Juruselamat. Cara ini disebut sebagai " the greatest simplicity (kesederhanaan terbesar)". Rasul Paulus dan Silas menyatakan kesederhanaan ini kepada kepala penjara Filipi saat mengatakan, "Percayalah kepada Tuhan Yesus Kristus dan engkau akan selamat, engkau dan seisi rumahmu" (Kis 16:31). Namun, walaupun jalan keselamatan itu sederhana, harga keselamatan itu mahal, yaitu hanya melalui pengorbanan Kristus (1 Pet. 1:18-19; Ibr. 9:11-28). 
5. Topik Pembelajaran dalam SPK

a. Keselamatan Menurut Alkitab.

Ada banyak kepercayaan yang mengajarkan bagaimana seseorang dapat diselamatkan. Setiap agama/ kepercayaan memiliki konsep keselamatan masing-masing yang berbeda satu dengan yang lainnya. Menurut ajaran Alkitab keselamatan itu adalah sebagai berikut.

1) Semua Manusia Berdosa (Rom. 3:23).

Sejak manusia pertama yaitu Adam dan Hawa jatuh ke dalam dosa, maka semua manusia telah berdosa dan terpisah dari Allah yang kudus. Akibat dari dosa itu adalah maut, yaitu hilangnya persekutuan dengan Allah dan api neraka sedang menunggu mereka ketika manusia itu mati (Rom 6:23).

2) Usaha Manusia Sia-Sia. (Efe. 2:8-9)

Segala usaha manusia untuk menyelamatkan dirinya sendiri adalah sia-sia. Baik agama, kesalehan, ilmu pengetahuan dan perbuatan baik adalah mustahil untuk menebus dosadosa kita. Manusia tidak dapat diselamatkan dan masuk sorga dengan usahanya sendiri melainkan melalui anugerah lewat pengorbanan Yesus di atas kayu salib.

3) Percaya Yesus Beroleh Keselamatan (Yoh. 3:16).

Allah mengasihi setiap kita orang yang berdosa. Allah mengutus Yesus untuk memikul dosa umat manusia di kayu salib (1 Pet. 2:24). Siapa yang percaya dan mengakui bahwa Yesus adalah Tuhan dan Juruselamat akan menerima anugerah keselamatan (Rom. 10:9-10).

\section{b. Jaminan Keselamatan}

Agar kita dapat bertumbuh dan berkembang dengan kuat, maka kita harus memiliki akan kepastian keselamatan. Alkitab mengajarkan kepada kita mengenai jaminan keselamatan yang jelas dan pasti sehingga setiap orang percaya memiliki kepastian akan keselamatan dirinya.

1) Keselamatan Terjadi Seketika (Yoh 5:24)

Keselamatan bukanlah hasil usaha tetapi adalah anugerah melalui imam percaya kepada Yesus Kristus (Efe 2:8-9). Keselamatan terjadi seketika bukan proses tetapi di saat kita percaya kepada Yesus Kristus maka pada saat itu juga secara otomatis kita akan pindah dari dalam maut kepada hidup yang kekal.

2) Status Anak Allah (Yoh 1:12) 
Pada saat kita menerima Yesus Kristus sebagai Tuhan dan Juru Selamat maka kita mendapat status anak Allah. Seseorang yang telah percaya dan mengalami kelahiran baru tidak membiarkan dirinya jatuh ke dalam dosa berlama lama. Segera ia bangkit kembali, sebab benih Ilahi ada di dalam dirinya (1 Yoh 3:8-9). Seorang anak Allah dapat jatuh ke dalam dosa tetapi ia tidak dapat hidup di dalam dosa.

3) Allah Menjamin Keselamatan Kita (Yoh 10:28-29)

Allah Tri Tunggal terlibat dalam memberikan jaminan keselamatan. Bapa sorgawi berjanji bahwa pasti tidak ada seorangpun dari orang yang percaya akan binasa dan tidak ada yang bisa merebut kita dari tangan Bapa. Yesus berjanji tidak akan membuang kita, Dia menjaga kita supaya jangan binasa dan akan dibangkitkan pada akhir jaman (Yoh 6:37-40). Roh Kudus memeteraikan orang percaya saat kita percaya, meterai adalah jaminan keselamatan kita pada hari penyelamatan nanti (Efe 1:13-14).

c. Baptisan Air

Baptisan air bukanlah suatu pilihan tetapi adalah sebuah ketetapan yang Allah berikan untuk dilakukan oleh setiap orang yang percaya kepada-Nya. Makna baptisan air yang sesungguhnya menurut Roma 6:3-14 adalah :

1. Bersatu dalam Kematian Kristus.

Ketika kita dibaptis air maka kita menhayati bahwa kita telah menjadi satu dengan kematian Kristus sehingga kita dapat melihat bahwa manusia lama kita telah mati bersama dengan Kristus.

2. Bersatu Dalam Penguburan Kristus.

Saat kita menerima baptisan air kita menghayati bahwa kita menjadi satu dengan penguburan Kristus sehingga kita dapat melihat bahwa manusia lama kita telah dikubur bersama dengan Kristus.

3. Bersatu Dalam Kebangkitan Kristus.

Ketika kita menerima baptisan air kita juga menghayati bahwa kita telah dibangkitkan bersama kebangkitan Kristus sehingga kita dapat melihat dan yakin bahwa kita telah bangkit menjadi manusia baru yang memiliki hidup kekal.

d. Kuasa Roh Kudus

Roh Kudus adalah pribadi ke 3 dari Allah Tri Tunggal. Ia harus kita cintai dan hormati seperti kita menghormati dan mencintai Allah Bapa dan Tuhan kita Yesus Kristus. Roh Kudus 
memiliki kuasa yaitu karunia-karunia Roh Kudus yang Yesus rindukan untuk dialirkan melalui hidup kita. Cara mengalirkan kuasa Roh Kudus adalah melalui :

1. Percaya Roh Kudus telah ada di dalam kita (Efe 1:13-14).

Pada saat kita percaya kepada Injil, kita telah menerima Roh Kudus di dalam hati kita. Roh Kudus menjadi meterai bahwa kita adalah milik Allah sepenuhnya.

2. Roh Kudus ingin kita menjadi berkat (Kis $1: 8$ )

Roh Kudus memenuhi hati kita tetapi bukan hanya kita yang menikmati berkat Allah itu melainkan kita jga menjadi berkat bagi orang lain. Roh Kudus memberikan kehausan untuk kita bersaksi kepada banyak orang sehingga hidup kita bisa menjadi berkat bagi orang lain.

3. Kita bertindak dengan mengalirkan kuasa Roh Kudus (Yoh 7:37-39).

Kuasa Roh Kudus bekerja dengan mengalirkan karunia-karunia Roh Kudus yang mengalir keluar dari dalam diri dan hidup kita sebagai orang percaya. Roh Kudus memiliki 9 karunia manifestasi (1 Kor 12:8-10) yaitu : Perkataan hikmat, perkataan pengetahuan, karunia iman, kesembuhan, mukjizat, bernubuat, membedakan roh,berbahasa Roh dan menafsirkan bahasa Roh.

\section{e. Murid Sejati}

Menjadi orang percaya adalah sama dengan menjadi murid Kristus. Setiap orang percaya harus menjadi murid Kristus dan berkewajiban untuk memuridkan orang lain. Ciriciri seorang murid sejati adalah :

1. Memiliki Iman Sejati.

Seseorang menjadi murid sejati apabila ia mengalami kelahiran baru. Kelahiran baru terjadi kalau ia memiliki iman sejati. Iman sejati didasari oleh kepercayaan bahwa Yesus adalah Tuhan dan Juruselamat.

2. Memiliki Buah Sejati (Yoh. 16:16).

Benih Kristus bukan hanya bertumbuh tetapi juga berbuah tetap. Buah yang dihasilkan adalah buah-buah jiwa yang dibawa dan dipersembahkan bagi kemuliaan nama Tuhan. Ada 3 jenis buah dalam kehidupan murid Kristus yaitu buah pertobatan, buah jiwa-jiwa dan buah pelayanan.

3. Menghasilkan Murid Kristus (Mat. 28:19-20). 
Yesus mengutus murid-murid-Nya untuk menghasilkan murid Kristus yang baru. Cara menghasilkan murid Kristus adalah melalui belajar dalam membina para petobat baru dan mau berkorban waktu maupun tenaga.

\section{f. Kesaksian}

Kesetiaan memberitakan Injil artinya kepatuhan dan ketaatan untuk menyampaikan Kabar Baik. Dalam penelitian ini kesetiaan dalam memberitakan Injil dimaknai sebagai segala usaha yang dilakukan (doa, bersaksi, kunjungan, dll) untuk memberitahukan kepada orang lain mengenai Injil yakni Kabar Baik tentang adanya keselamatan di dalam Tuhan Yesus Kristus. Istilah lain yang biasa dipakai untuk menyatakan hal tersebut di atas adalah "Bersaksi." Peter Wagner, berkata : "Membawa berita Injil yang dapat memindahkan orangorang dari kegelapan kepada terang berarti telah melaksanakan amanat penginjilan". ${ }^{6}$ Inilah yang dimaksud Yesus ketika Ia mengutus murid-murid-Nya untuk menjadikan semua bangsa murid. Perintah pertama Kristus kepada para pengikut-Nya yang baru dalam Injil Markus pasal 1: "Mari, ikutlah Aku, dan kamu akan Ku-jadikan penjala manusia." Perintah terakhirNya di bumi kepada murid-murid-Nya adalah: "Tetapi kamu akan menerima kuasa, kalau Roh Kudus turun ke atas kamu, dan kamu akan menjadi saksi-Ku di Yerusalem dan di seluruh Yudea dan Samaria dan sampai ke ujung bumi."

Demikian Kristus memulai dan mengakhiri pelayanan-Nya dengan perintah menjadi saksi dan penjala manusia. Sasaran ajaran-Nya disimpulkan dalam Amanat Agung, yaitu perintah Yesus kepada pengikut-Nya untuk pergi ke seluruh dunia dan memberitakan Injil kepada setiap insan. Maka prinsip yang utama dan jelas adalah bahwa setiap orang percaya mempunyai tugas di bawah pimpinan Roh Kudus untuk mengabarkan Injil kepada setiap orang yang belum menerima Yesus sebagai Tuhan dan Juru Selamat.Untuk sampai bisa bersaksi para petobat baru perlu mendapatkan pembinaan rohani dan pembekalan sehingga ketika ada pertanyaan dan sanggahan di lapangan dia bisa menjawab dan mengatasinya yang berakhir dengan penjangkauan jiwa-jiwa untuk masuk ke dalam proses pemuridan di SPK.

Ketika seseorang bertobat dan dipulihkan dari cara hidupnya yang lama (dosa), maka akan timbul suatu antusiasme dalam hidupnya untuk memberikan kesaksian apa yang sedang dialaminya. Kesaksian yang disampaikan akan menjadi hidup karena apa yang disampaikan adalah merupakan suatu realita kehidupan yang dialaminya. Lingkungan yang dijadikan obyek kesaksiannya adalah lingkungan lama di mana biasanya dia berkomunitas dan

${ }^{6}$ C.Peter Wagner, Strategi Perkembangan Gereja (Gandum Mas: Malang, n.d.), 186. 
umumnya lingkungan itu adalah lingkungan yang tidak taat kepada firman Tuhan. Kesaksian yang disampaikan akan banyak mendapat tanggapan dari komunitas lamanya, baik yang mendukung maupun yang sebaliknya.

Bukan pada hari-hari pertama saja orang-orang Kristen bersaksi, tetapi mereka bersaksi setiap hari dan kepada setiap orang yang mereka jumpai. Khususnya kepada orangorang yang menjadi sahabat, keluarga, kenalan, dan tetangga mereka. Sangat jelas dalam Perjanjian Baru bahwa menginjil bukan merupakan sebuah kegiatan khusus yang dilakukan pada waktu tertentu, seperti sekali dalam setahun, kunjungan sekali seminggu, tetapi merupakan kegiatan yang terus berlangsung oleh individu dan juga secara bersama yang menyebarkan pengalaman dan pengetahuan mengenai Kristus. Setiap orang Kristen bertanggung jawab untuk menyatakan Injil dalam kehidupan sehari-hari. Kristus di sumur (Yoh.4), Andreas dengan saudaranya Petrus (Yoh.1), Filipus dengan saudaranya Natanael (Yoh.1), Petrus di gerbang Bait Allah (Kis.3), dan Paulus dalam penjara di Filipi (Kis.16:2234) adalah contoh-contoh yang jelas tentang bagaimana Kristus dan orang percaya mula-mula menggunakan hubungan-hubungan mereka sebagai jembatan menyebarkan Injil.

Dalam ledakan penginjilan perlu melatih kaum awam bukan hanya untuk bersaksi melalui kunjungan seminggu sekali dan dalam praktik lapangan, tetapi sepanjang minggu sebagai suatu gaya hidup kepada orang-orang yang mereka sudah kembangkan hubungan kepercayaan. Kaum awam agar terus dilatih untuk mengembangkan hubungan-hubungan baru, sehingga mereka dapat bercerita tentang Kristus. Kemudian mereka juga dilatih cara bersaksi dengan efektif supaya ketika kesempatan muncul, mereka sudah siap untuk membagi Injil kepada orang-orang yang sudah dipersiapkan oleh Allah, Roh Kudus. ${ }^{7}$

Yohanes 4:39 yang berkata "Dan banyak orang Samaria dari kota itu telah menjadi percaya kepada-Nya karena perkataan perempuan itu, yang bersaksi: Ia mengatakan kepadaku segala sesuatu yang telah kuperbuat”. Perempuan Samaria itu adalah petobat baru yang dipakai oleh Yesus untuk menjadi saksi bagi orang-orang Samaria yang tidak percaya kepada Yesus. Petobat baru perlu mendapat pendampingan dan pemuridan yang terus menerus karena biasanya mereka akan mendapat cukup banyak perlawanan dari komunitas lamanya. Komsel adalah wadah yang sangat tepat untuk membentuk petobat baru melakukan perubahan hidup dan juga untuk lebih mengerti akan firman Tuhan dengan baik.

${ }^{7}$ G Gidion, "Jurnal Memahami Pekerjaan Roh Kudus Dalam Pelayanan Gereja Berdasarkan 1 Dan 2 Timotius," Harvester Journal (2019), http://ejournal.sttharvestsemarang.ac.id/index.php/harvester/article/view/14. 


\section{KESIMPULAN}

Kesimpulan dari hasil penelitian yang telah dilakukan dan saran-saran penting yang dianggap perlu disampaikan agar hasil penemuan ini menjadi bermanfaat bagi gereja yang akan memanfaatkan program SPK di dalam pemuridan jemaat. Hasil penemuan ini secara khusus tentunya akan sangat bermanfaat untuk pengurus gereja Mahanaim Community Church Semarang. Hasil penemuan yang ada bisa dipakai sebagai rekomendasi untuk lebih meningkatkan lagi efektivitas pengenalan akan Kristus di gereja Mahanaim Community Church Semarang. Berdasarkan hasil dari penelitian yang dilakukan di Mahanaim Community Church dapat disimpulkan bahwa, berdasarkan perbandingan nilai $\mu 0$ (114) dengan nilai rata-rata empiris $(179,05)$, diperoleh bahwa nilai yang rata-rata empiris $(179,05)$ lebih besar dari nilai $\mu 0$ (114), maka hipotesis nol yang berbunyi diduga tingkat kecenderungan efektivitas pengenalan akan Kristus dalam pemuridan SPK di Mahanaim Community Church Semarang berada dalam kategori sedang atau $=60 \%$ dinyatakan ditolak. Oleh karena hipotesis nol ditolak, maka hipotesis alternative yang berbunyi diduga tingkat kecenderungan efektivitas pengenalan akan Kristus dalam pemuridan SPK di Mahanaim Community Church Semarang tidak berada dalam kategori sedang atau $\neq 60 \%$ dinyakan diterima. Selanjutnya berdasarkan perhitungan diperoleh nilai variabel nilai efektivitas pengenalan akan Kristus dalam pemuridan SPK di Gereja Mahanaim Community Church Semarang adalah sangat tinggi (94,2\%). 


\section{DAFTAR PUSTAKA}

G Gidion. “Jurnal Memahami Pekerjaan Roh Kudus Dalam Pelayanan Gereja Berdasarkan 1 Dan 2 Timotius.” Harvester Journal (2019). http://ejournal.sttharvestsemarang.ac.id/index.php/harvester/article/view/14.

Gidion. "Efektifitas Kepemimpinan Yang Memberdayakan Dalam Meningkatkan Pertumbuhan Gereja Di Gereja Jemaat Kristen Indonesia Maranatha Ungaran.” Shift Key 8, no. 1 (2018): 16-33. http://jurnal.sttkao.ac.id/index.php/shiftkey/article/view/14.

—. "Efektifitas Kepemimpinan Yang Memberdayakan Dalam Meningkatkan

Pertumbuhan Gereja Di Gereja Jemaat Kristen Indonesia Maranatha Ungaran.” Shift Key 8, no. 1 (2018): 16-33.

—_. "Profesionalitas Layanan Gereja." Shift Key 7, no. 2 (2017): 89-104.

Siregar, Syofian. Statistik Parametrik Untuk Penelitian Kuantitatif. Jakarta: Bumi Aksara, 2014.

Sugiyono. "Metode Penelitian Kombinasi (Mixed Methods)." Bandung: Alfabeta (2010). Wagner, C.Peter. Strategi Perkembangan Gereja. Gandum Mas: Malang, n.d. 